\title{
Effect of pediatric palliative care programs on health care resource utilization and costs among children with life-threatening conditions: a systematic review of comparative studies
}

\author{
Tania Conte RN, Craig Mitton PhD, Logan M. Trenaman BSc, Negar Chavoshi MSc, Harold Siden MD MHSc
}

Abstract

Background: Pediatric palliative care is a relatively new and evolving field, and the cost of pediatric palliative care programs is unclear. We conducted a systematic review to compare inpatient health care utilization and costs among children with life-threatening conditions who have accessed a pediatric palliative care program and those who have not.

Methods: We searched MEDLINE, Embase, CINAHL and LILACS databases from January 2000 to July 2013 , as well as the grey literature, for experimental or observational studies that compared pediatric palliative care programs with usual care. Outcomes of interest included hospital admissions, length of stay and health care costs.

Results: Of the 5193 records identified, we reviewed 109 in full and included 11 in our study. The overall quality of the studies was moderate to low. We observed mixed results for all outcomes. Compared with patients receiving usual care, fewer patients in the palliative care group had hospital admissions and fewer of those with cancer had planned hospital admissions. In contrast, no effects were observed regarding the overall number of hospital, emergency or outpatient admissions. Conflicting results were observed with regards to critical care utilization. Studies showed a trend toward shorter lengths of stay in hospital in the palliative care group. However, a single study that also considered inpatient time in hospice facilities found an increase in total length of stay, which showed a shift in the setting of health care utilization. We observed no conclusive trend in the effects on cost.

Interpretation: Evidence suggests that pediatric palliative care programs may result in a shift of utilization to other health care settings beyond hospital care. These settings should be considered when measuring resource utilization and costs.

$\mathrm{P}$ ediatric palliative care can be summarized as "an active and total approach to care focused on the enhancement of quality of life for the children with life-threatening conditions and support for the family". ${ }^{1}$ A life-threatening condition is a condition with no established cure, or for which available treatment has not succeeded, and survival to full adulthood is unlikely. Children requiring, but not enrolled in, a pediatric palliative care program (PPCP) access usual care often through uncoordinated acute care admissions and some episodes of home care, but potentially with some compromise to continuity of care where critical components for family support are lacking. Complex care plans and fluctuating patient needs necessitate a coordination of care within individualized support systems.

Pediatric palliative care is a relatively new and evolving field. It varies from adult palliative care in important ways. From a resource utilization perspective, pediatric palliative care is usually delivered over a longer time frame.,3
It is unclear how enrolment in a PPCP affects health care utilization and costs compared with usual care. Understanding such outcomes may improve the efficiency of health care services for children with life-threatening conditions and support evidence-based planning and resource allocation for PPCPs. We conducted a systematic review of the published literature where inpatient health care resource utilization and costs were compared between children with life-threatening conditions who accessed a PPCP and those who did not.

Competing interests: None declared.

This article has been peer reviewed.

Correspondence to: Tania Conte, tconte@alumni.ubc.ca

CMAJ Open 2015.DOI:10.9778/cmajo.20140044 


\section{Methods}

\section{Search strategy}

The systematic review was performed according to PRISMA guidelines. ${ }^{4}$ We searched MEDLINE, Embase, CINAHL and LILACS databases. For feasibility, and given the relatively recent development of PPCPs, we limited the search to articles published after 2000. The search was completed on July 18, 2013, with weekly automated alerts for publications after this date. No language restrictions were applied. Complementary scanning of reference lists, consultation with experts and searches of grey literature were also undertaken. The search strategies are shown in Appendix 1 (available at www.cmajopen.ca/content/3/1/E68/suppl/DC1).

We included published articles and abstracts describing comparative studies (randomized clinical trials, experimental or observational studies, and secondary administrative database analyses), regardless of the length of the observation period. Studies were eligible if they included a comprehensive PPCP or its components (e.g., palliative care consultation, respite care, end-of-life care or planning, hospice and community-based palliative care) and they exclusively included children with life-threatening conditions who were 22 years of age or younger. Although there is no consistency to the upper age limit in this population, ${ }^{1,5}$ programs can support transition to adult palliative care services up to the age of 22 (e.g., the Seattle Pediatric Palliative Care Project $\left.{ }^{\dagger}\right)$.

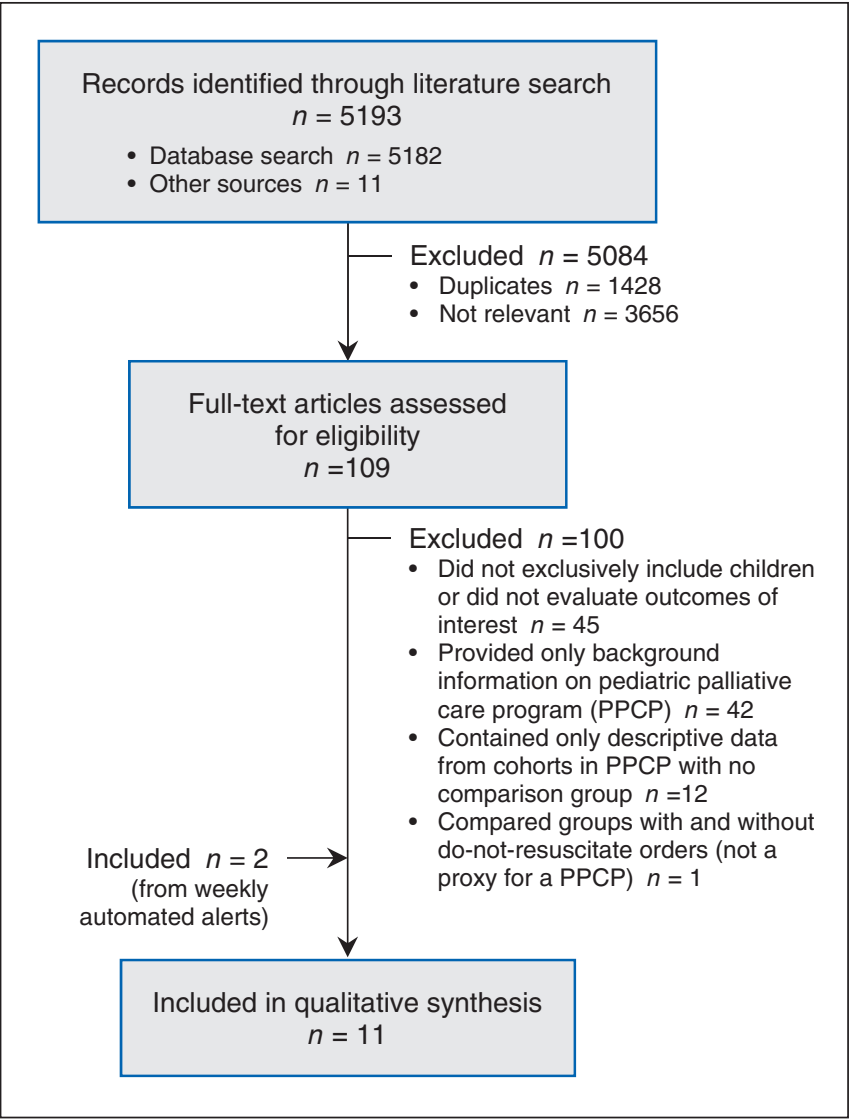

Figure 1: Flow diagram of study selection.
Outcomes included potential quality of end-of-life indicators that were identified by the established adult literature and were measureable from administrative data. ${ }^{7}$ Our primary outcomes of interest were utilization of health care resources, including hospital admissions and length of stay; and health care costs (direct, indirect and total expenditures). Secondary outcomes of interest included resource utilization in the last admission before death, as measured by length of stay, number of invasive procedures to prolong life and number of resuscitative attempts.

\section{Study selection, quality assessment and data extraction}

Two researchers (T.C. and L.M.T.) conducted independent reviews of titles and abstracts identified in the literature search. Discrepancies were resolved by discussion or the involvement of a third reviewer with clinical expertise in PPCPs (H.S.). Data were extracted by the same 2 who conducted the study selection, to ensure consistency of reporting. Discrepancies were handled in the same manner as study identification. Study characteristics were displayed in tables, to assist in exploration of each study's approach to program evaluation. A meta-analysis was not feasible because of considerable heterogeneity in study populations, outcome measures, observation periods and reporting of PPCP components. We assessed the included full-text articles for study quality using the Newcastle-Ottawa Scale ${ }^{8}$ (detailed in Appendices 2 and 3, available at www.cmajopen.ca/content/3/1/E68/suppl/DC1). According to the scale, a study is judged on 3 broad perspectives: the selection of the study groups; the comparability of the groups; and the ascertainment of the outcome. The greater the number of stars (maximum 9), the higher the quality of the article.

\section{Results}

\section{Study selection}

Using the search strategy, we retrieved 5193 records, 1428 of which were duplicates. We excluded a further 3656 after screening the titles and abstracts, and retrieved 109 papers for full-text review $(\kappa$ value $=0.25,95 \%$ confidence interval $[\mathrm{CI}]$ $0.22-0.28$, indicating fair agreement according to Fleiss ${ }^{9}$ ). Nine articles fulfilled the inclusion criteria (Figure 1), ${ }^{5,10-17}$ $(\kappa=0.83,95 \%$ CI $0.64-1.00$, indicating almost perfect agreement). Two additional studies ${ }^{18,19}$ were identified in the weekly automated search updates, for a total of 11 included studies.

\section{Study characteristics}

All of the 11 studies were retrospective observational studies. Full descriptive characteristics are presented in Appendix 3 (available at www.cmajopen.ca/content/3/1/E68/supp1/DC1) and summarized in Table 1.

Four cohort comparisons ${ }^{11,12,14,15}$ used administrative data and survey techniques ${ }^{14}$ to explore differences between cohorts of children with and without access to PPCPs. Observation periods varied, from the last day of admission before death to the referral to a PPCP. Two articles included only 


\begin{tabular}{|c|c|c|c|c|c|c|c|}
\hline Study & Participants & $\begin{array}{l}\text { Study } \\
\text { design }\end{array}$ & $\begin{array}{l}\text { Observation } \\
\text { period }\end{array}$ & $\mathrm{n}$ & $\begin{array}{l}\text { Intervention } \\
\text { group }\end{array}$ & $\begin{array}{l}\text { Comparison } \\
\text { group }\end{array}$ & Outcome measures \\
\hline $\begin{array}{l}\text { Postier et al., } \\
2014^{18}\end{array}$ & $\begin{array}{l}\text { Age 1-21 yr } \\
\text { Enrolled in home } \\
\text { PPCP/hospice } \\
\text { program }\end{array}$ & $\mathrm{RChBA}^{*}$ & $\begin{array}{l}\text { Before: } 1 \mathrm{yr} \\
\text { After: } 1 \mathrm{yr}\end{array}$ & 425 & After PPCP & $\begin{array}{l}\text { Before } \\
\text { PPCP }\end{array}$ & $\begin{array}{l}\text { Change in no. of } \\
\text { hospital admissions, } \\
\text { LOS and total billed } \\
\text { charges for hospital/ED } \\
\text { stay }\end{array}$ \\
\hline $\begin{array}{l}\text { Fraser et al., } \\
2013^{11}\end{array}$ & $\begin{array}{l}\text { Age } \leq 19 \mathrm{yr} \\
\text { Death from cancer }\end{array}$ & RCS & $\begin{array}{l}\text { Referral to } \\
\text { death }\end{array}$ & 497 & $\begin{array}{l}\text { Hospice group } \\
(n=132)\end{array}$ & $\begin{array}{l}\text { Control } \\
\text { group } \\
(n=311)\end{array}$ & $\begin{array}{l}\text { Total no. of hospital } \\
\text { admissions, no. of } \\
\text { planned hospital } \\
\text { admissions, no. of } \\
\text { emergency } \\
\text { admissions }\end{array}$ \\
\hline $\begin{array}{l}\text { Keele et al., } \\
2013^{12}\end{array}$ & $\begin{array}{l}\text { Age }<18 \mathrm{yr} \\
\text { Death in hospital } \\
\text { from any } \\
\text { cause }>5 \mathrm{~d} \text { after } \\
\text { admission }\end{array}$ & RCS & $\begin{array}{l}\text { Last } \\
\text { admission } \\
\text { before death }\end{array}$ & 24342 & $\begin{array}{l}\text { PC group } \\
(n=919)\end{array}$ & $\begin{array}{l}\text { No PC } \\
(n= \\
23423)\end{array}$ & $\begin{array}{l}\text { Age, sex, LOS, major } \\
\text { group category } \\
\text { diagnostic, } \\
\text { medications, } \\
\text { procedures in last } \\
\text { admission }\end{array}$ \\
\hline $\begin{array}{l}\text { Arland et al., } \\
2013^{10}\end{array}$ & $\begin{array}{l}\text { Age } 1 \text { mo-19 yr } \\
\text { Death from brain } \\
\text { tumour }\end{array}$ & RChBA† & $\begin{array}{l}\text { Before: } 5 \mathrm{yr} \\
\text { After: } 10 \mathrm{yr}\end{array}$ & 114 & $\begin{array}{l}\text { After group } \\
(n=92)\end{array}$ & $\begin{array}{l}\text { Before } \\
\text { group } \\
(n=22)\end{array}$ & $\begin{array}{l}\text { Symptoms, hospital } \\
\text { admissions (no., } \\
\text { LOS), location of } \\
\text { death }\end{array}$ \\
\hline $\begin{array}{l}\text { Smith et al., } \\
2013^{19}\end{array}$ & $\begin{array}{l}\text { Children (age not } \\
\text { defined) } \\
\text { Hospital costs after } \\
\text { discharge were in } \\
\text { top tenth percentile }\end{array}$ & $\begin{array}{l}\text { RCS } \\
+\mathrm{RChBA}^{*}\end{array}$ & $\begin{array}{l}\text { RCS: up to } \\
2 \mathrm{yr} \\
\text { RChBA: } \\
\text { undisclosed }\end{array}$ & 1001 & $\begin{array}{l}\text { PPCP group } \\
(n=81)\end{array}$ & $\begin{array}{l}\text { Control } \\
\text { group } \\
(n=920)\end{array}$ & $\begin{array}{l}\text { Cost, demographics, } \\
\text { use of technology }\end{array}$ \\
\hline $\begin{array}{l}\text { Gans et al., } \\
2012^{5}\end{array}$ & $\begin{array}{l}\text { Age } \leq 20 \text { yr } \\
\text { Life-threatening } \\
\text { condition } \\
\text { Enrolled in PPCP }\end{array}$ & $\mathrm{RChBA}^{*}$ & $\begin{array}{l}\text { Before: } 12 \mathrm{mo} \\
\text { After: } 18 \mathrm{mo}\end{array}$ & 123 & After PPCP & $\begin{array}{l}\text { Before } \\
\text { PPCP }\end{array}$ & $\begin{array}{l}\text { LOS, medical } \\
\text { expenditures, family's } \\
\text { quality of life and } \\
\text { satisfaction }\end{array}$ \\
\hline $\begin{array}{l}\text { Pascuet et } \\
\text { al., } 2010^{13}\end{array}$ & $\begin{array}{l}\text { Children (age not } \\
\text { defined) } \\
\text { Used respite at } \\
\text { pediatric hospice }\end{array}$ & $\mathrm{RChBA}^{*}$ & $\begin{array}{l}\text { Before: } 1 \mathrm{yr} \\
\text { After: } 1 \mathrm{yr}\end{array}$ & 66 & After respite & $\begin{array}{l}\text { Before } \\
\text { respite }\end{array}$ & $\begin{array}{l}\text { LOS, ED and } \\
\text { outpatient visits, } \\
\text { overall cost in } \\
\text { hospital/hospice } \\
\text { admission }\end{array}$ \\
\hline $\begin{array}{l}\text { Dussel et al., } \\
2009^{14}\end{array}$ & $\begin{array}{l}\text { Children (age not } \\
\text { defined) } \\
\text { Death from cancer }\end{array}$ & $\begin{array}{l}\text { XS survey } \\
+ \text { RCS }\end{array}$ & $\begin{array}{l}\text { Last month } \\
\text { of life }\end{array}$ & 140 & $\begin{array}{l}\text { Location of } \\
\text { death planned } \\
(n=88)\end{array}$ & $\begin{array}{l}\text { Location of } \\
\text { death not } \\
\text { planned } \\
(n=52)\end{array}$ & $\begin{array}{l}\text { End-of-life planning, } \\
\text { end-of-life support } \\
\text { from physicians, use } \\
\text { of home care, hospital } \\
\text { resource utilization, } \\
\text { place of death }\end{array}$ \\
\hline $\begin{array}{l}\text { Knapp et al., } \\
2009^{15}\end{array}$ & $\begin{array}{l}\text { Age } 1-21 \mathrm{yr} \\
\text { Death from any } \\
\text { cause }\end{array}$ & RCS & $\begin{array}{l}\text { Last year of } \\
\text { life }\end{array}$ & 1527 & $\begin{array}{l}\text { Hospice } \\
(n=85)\end{array}$ & $\begin{array}{l}\text { No hospice } \\
(n=848)\end{array}$ & $\begin{array}{l}\text { Hospice use, hospice } \\
\text { expenditures, other } \\
\text { expenditures }\end{array}$ \\
\hline $\begin{array}{l}\text { Ward-Smith } \\
\text { et al., 2008 }\end{array}$ & $\begin{array}{l}\text { Children (no age } \\
\text { bracket defined) } \\
\text { Enrolled in PPCP }\end{array}$ & $\mathrm{RCS} \S$ & $\begin{array}{l}6 \text { mo before } \\
\text { death }\end{array}$ & 18 & $\begin{array}{l}\text { PPCP group } \\
(n=9)\end{array}$ & $\begin{array}{l}\text { Non-PPCP } \\
\text { group } \\
(n=9)\end{array}$ & $\begin{array}{l}\text { Total hospital costs, } \\
\text { LOS, differences in } \\
\text { types of procedures }\end{array}$ \\
\hline $\begin{array}{l}\text { Belasco } \\
\text { et al., } 2000^{16}\end{array}$ & $\begin{array}{l}\text { Children (no age } \\
\text { bracket defined) } \\
\text { Referred to home } \\
\text { PPCP }\end{array}$ & $\begin{array}{l}\text { Case } \\
\text { series }\end{array}$ & $1 \mathrm{~d}$ & 3 & Home care & $\begin{array}{l}\text { Hospital } \\
\text { care }\end{array}$ & $\begin{array}{l}\text { Type of interventions } \\
\text { delivered, place of } \\
\text { death, comparison of } \\
\text { charges of care }\end{array}$ \\
\hline \multicolumn{8}{|c|}{$\begin{array}{l}\text { Note: } E D=\text { emergency department, LOS }=\text { length of stay, PC = palliative care, PPCP = pediatric palliative care program, RChBA = retrospective cohort before-after study } \\
\text { with no control, RCS = retrospective cohort study, XS = cross-sectional study. } \\
\text { *The same patients were followed before and after the intervention with no controls. } \\
\text { †Different cohorts of patients were followed before and after the intervention (historical cohort comparison). } \\
\text { †Length of "before" follow-up period unclear. }\end{array}$} \\
\hline
\end{tabular}


cancer-related deaths, ${ }^{11,14}$ and two included deaths from any cause. ${ }^{12,15}$ The interventions by which children were classified as being in the PPCP group included use of a PPCP (program or hospice provider ${ }^{11,15}$ ) or inpatient palliative care consultation. ${ }^{12}$ One study focused on an important element of PPCP, advance care planning, as identified by parental planning of the child's location of death. ${ }^{14}$ Three studies were based in the United States ${ }^{12,14,15}$ and one in the United Kingdom. ${ }^{11}$

Four before-after studies used administrative data ${ }^{5,18}$ and chart reviews ${ }^{10,13}$ to explore differences in outcomes before and after access to a PPCP. Three of the studies compared outcomes in the same group of patients before and after program enrolment and included children with life-threatening conditions. ${ }^{5,13,18}$ The other study compared historical cohorts of children with brain tumours before and after implementation of a standardized program for end-of-life care. ${ }^{10}$ Observation periods varied, from 12 months to 10 years. Determining the point at which children entered the program was based on hospice use, ${ }^{13}$ explicit enrolment in the program ${ }^{5,18}$ or the date of program implementation. ${ }^{10}$ Three studies were based in the $\mathrm{US}^{5,10,18}$ and one in Canada. ${ }^{13}$

One article was classified as a case-control study by the authors, but it was actually a cohort comparison. ${ }^{17}$ This US study relied on administrative data to compare children enrolled in a PPCP with those who were not, 6 months before death.

One conference abstract ${ }^{19}$ described a cohort comparison that was combined with a before-after analysis of the PPCP group based on administrative data in the US. It identified the PPCP group by the presence of a palliative care consultation and had a 2-year observation period.

The last article, a case series from the US, ${ }^{16}$ included only 3 patients. The authors observed procedures received in 1 day of home-based PPCP and compared the costs with those of procedures received in hospital.

Table 2: Summary of quality assessment

\begin{tabular}{|c|c|c|c|}
\hline \multirow[b]{2}{*}{ Study* } & \multicolumn{3}{|c|}{$\begin{array}{l}\text { Newcastle-Ottawa Scale } \\
\text { quality assessment score }\end{array}$} \\
\hline & $\begin{array}{c}\text { Selection } \\
\text { (max } 4 \text { stars) }\end{array}$ & $\begin{array}{l}\text { Comparability } \\
\text { (max } 2 \text { stars) }\end{array}$ & $\begin{array}{c}\text { Outcome } \\
\text { (max } 3 \text { stars) }\end{array}$ \\
\hline Postier et al. ${ }^{18}$ & $\star \star$ & $\star$ & $\star \star \star$ \\
\hline Fraser et al. ${ }^{11}$ & $\star \star \star$ & $\star$ & $\star \star$ \\
\hline Knapp et al. ${ }^{15}$ & $\star \star \star$ & $\star$ & $\star \star$ \\
\hline Keele et al. ${ }^{12}$ & $\star \star \star$ & $\star$ & $\star$ \\
\hline Arland et al. ${ }^{10}$ & $\star \star \star$ & & $\star \star$ \\
\hline Dussel et al. ${ }^{14}$ & $\star \star \star$ & & $\star$ \\
\hline $\begin{array}{l}\text { Ward-Smith } \\
\text { et al. }{ }^{17}\end{array}$ & $\star$ & & $\star \star$ \\
\hline Gans et al. ${ }^{5}$ & $\star$ & $\star$ & $\star$ \\
\hline Pascuet et al. ${ }^{13}$ & $\star \star$ & & $\star$ \\
\hline
\end{tabular}

\section{Quality assessment}

According to the Newcastle-Ottawa Scale quality assessment, 5 of the articles received five or six stars, and 6 received four stars or less. Studies were classified as having moderate to high risk of bias (Table 2; Appendix 4 at www.cmajopen.ca /content/3/1/E68/suppl/DC1).

Numerous studies had limitations in their methodology. For example, one study ${ }^{12}$ included only children who died 5 or more days after admission; the authors excluded individuals who did not choose life-extending measures to prolong their stay beyond 5 days and children who were discharged to die at home. This definition would affect both hospital admissions and costs, leaving the true difference between programs to be greater. Furthermore, the PPCP group was identified via billing codes for palliative care encounter (ICD-9 code V66.7). If the services were billed under the code of the primary condition, children in the palliative care program would have been misclassified to the usual care group. The direction and magnitude of this bias is uncertain. In another study, ${ }^{11}$ the authors did not measure or control whether children were still in disease-directed treatment in both groups - a factor for decreased planned admissions. It is also unclear whether admissions to the hospice for symptom management were included in the overall number of admissions, making it uncertain whether the results represent a shift in health care setting or a decrease in resource utilization. In addition, the conference abstract ${ }^{19}$ did not present sufficient information on methodology.

Only 2 studies addressed confounding in the outcome analysis. ${ }^{11,18}$ One study ${ }^{11}$ investigated the effect on the number of hospital admissions in a cohort PPCP hospice cohort from time of referral to death. The authors controlled for age, disease, sex and Townsend deprivation score. The deprivation score $^{20}$ is based on unemployment, non-car ownership, nonhome ownership and household overcrowding. The authors did not address survival bias (whether the length of the study period was similar between groups) or include the number of hospice admissions in the PPCP group. Therefore, the number of hospital admissions in the PPCP group must be interpreted with caution because of shifts in care setting rather than decreases in health care utilization. The other study was a before-after study ${ }^{18}$ that controlled for time exposed to a palliative care program; however, because the authors did not include a control group for comparison, it was unclear whether the observed decrease in length of stay and costs in the PPCP period was a consequence of the program or a natural trend among patients approaching death. In addition, the authors did not control for place of death and costs associated with home care, both of which can bias results.

\section{Effect on admissions}

Seven articles investigated admissions ${ }^{10-14,18,19}$ (Table 3). Four did so by measuring the proportion of patients who had some type of admission ${ }^{10,12,14,19}$ and 3 measured number of hospital admissions. ${ }^{11,13,18}$ Among PPCP recipients, the proportion of patients with hospital admissions decreased. ${ }^{10,14}$ Although no effect on the number of patients with emergency admissions 


\section{OPEN}

was found, ${ }^{14}$ findings on the proportion of patients using critical care were conflicting. ${ }^{12,19}$ Exclusion of articles with the lowest quality assessment ( $\leq 4$ stars) seemed to favour PPCP. With respect to number of hospital admissions, we found no difference in overall admissions, emergency visits and outpatient visits after implementation of a PPCP, ${ }^{13,18}$ or between PPCP users and controls. ${ }^{11}$ Among cancer patients, one study showed a decrease in planned hospital admissions in the PPCP group, ${ }^{11}$ and another study reported an increase in the number of hospital admissions with longer exposure to $\mathrm{PPCP}^{18}$ - a reflection of survival. Exclusion of articles with the lowest quality assessments did not alter the results.

\section{Effect on length of stay}

Six studies investigated the influence of PPCP on length of stay $^{5,10,13,14,17,18}$ (Table 4). Most showed a decrease in hospital length of stay associated with PPCP..$^{5,10,13,14,18}$ However, statistical significance was not tested or reached in some of the articles. ${ }^{5,10,14}$ One study found no difference between groups. ${ }^{17}$ The only study that explicitly included combined length of stay in hospital and hospice found an overall increase in length of stay. ${ }^{13}$ Exclusion of the articles that did not test for significance resulted in complete discordance between studies.

\section{Effect on health care costs}

Eight studies measured the influence of PPCP on health care costs $^{5,12,13,15-19}$ (Table 5). Studies were heterogeneous and had conflicting results. Six articles showed reduced costs associated with PPCP. ${ }^{5,12,13,16-18}$ Two articles reported increased costs among PPCP users compared with controls; ${ }^{15,19}$ no sig- nificant difference in costs was found after implementation of PPCP. ${ }^{19}$ However, most authors failed to test for significance. ${ }^{5,15-17}$ Exclusion of these articles and the studies with the lowest quality assessments ${ }^{5,13,16}$ did not change the findings. Two studies with comprehensive outcome measures across hospice and hospital costs had conflicting results with regard to the direction of effects: a decrease in costs in the Canadian health care setting ${ }^{13}$ and an increase in the American setting. ${ }^{15}$

\section{Secondary outcomes}

Only one study compared length of stay during the last admission before death. ${ }^{12}$ The authors reported a shorter median stay among children who died from any cause and had access to palliative care consultation than among those without such consultation (17 d [interquartile range (IQR) 9-36] v. 21 d [IQR 10-47], $p<0.001)$.

\section{Resource utilization in the last admission before death}

Two cohort studies reported on the use of invasive procedures to prolong life during the last admission before death. One study ${ }^{12}$ found that, among children who died from any cause, those with a palliative care consultation had a significantly lower relative risk (RR) of receiving certain procedures. These included invasive mechanical ventilation (RR $0.14,95 \%$ CI $0.12-0.16$ ), adrenergics (RR $0.15,95 \%$ CI $0.11-0.2$ ), sedatives (RR 0.25, 95\% CI 0.2-0.3) and analgesics (RR 0.53, 95\% CI $0.47-0.6)$. These children also had a higher probability of receiving noninvasive mechanical ventilation ( $\mathrm{RR} 1.6,95 \% \mathrm{CI}$ 1.3-1.9) and intracranial pressure monitoring or extraventric-

Table 3: Effect of pediatric palliative care programs versus usual care on admissions

\begin{tabular}{|c|c|c|}
\hline Study* & Summary & Outcome \\
\hline Arland et al. ${ }^{10}$ & Decrease & $\begin{array}{l}54 \% \text { with admissions before program ( } 5 \mathrm{yr} \text { ) v. } 29 \% \text { after program ( } 10 \mathrm{yr} \text { ) } ; p<0.05 \\
46 \% \text { fewer admissions }\end{array}$ \\
\hline Dussel et al. ${ }^{14}$ & $\begin{array}{l}\text { No difference/ } \\
\text { controversial }\end{array}$ & $\begin{array}{l}54 \%(47 / 87) \text { with admissions in intervention group v. } 98 \%(51 / 52) \text { in control group; } p<0.001 \\
\text { No difference in emergency department visits: } 6 \%(5 / 84) \text { v. } 16 \%(8 / 50) ; p=0.057\end{array}$ \\
\hline Keele et al. ${ }^{12}$ & Decrease & Relative risk of ICU admissions lower in intervention group: 0.29 (95\% $\mathrm{Cl} 0.26-0.32)$ \\
\hline Smith A et al. ${ }^{19}$ & $\begin{array}{l}\text { No difference/ } \\
\text { controversial }\end{array}$ & $\begin{array}{l}\text { PICU admissions: } 90 \%(73 / 93) \text { of patients in intervention group v. } 56 \%(522 / 920) \text { in control } \\
\text { group; } p<0.001 \\
\text { NICU admissions: } 17 \%(14 / 93) \text { in intervention group v. } 28 \%(262 / 920) \text { in control group; } \\
p=0.04\end{array}$ \\
\hline Postier et al. ${ }^{18}$ & $\begin{array}{l}\text { No difference/ } \\
\text { controversial }\end{array}$ & $\begin{array}{l}\text { Mean no. of admissions } \pm \text { SD: } 3.09 \pm 3.6 \text { before v. } 3.18 \pm 4.3 \text { after intervention; } p=0.538 \\
\text { Interaction: level of exposure to program, cancer or not, study period }(p<0.001) \text {, adjusting } \\
\text { for other demographic and clinical characteristics }\end{array}$ \\
\hline Fraser LK et al. ${ }^{11}$ & $\begin{array}{l}\text { No difference/ } \\
\text { controversial }\end{array}$ & $\begin{array}{l}\text { Total hospital admissions (controlled for age, disease, sex, deprivation category): IRR } 0.79 \\
\text { (Cl } 95 \% 0.59 \text { to } 1.05 \text { ); } p=0.10 \\
\text { Planned hospital admissions: IRR } 0.60 \text { (CI } 95 \% 0.43 \text { to } 0.85 \text { ); } p=0.004 \\
\text { Emergency department visits: IRR } 1.15 \text { (Cl } 95 \% 0.84 \text { to } 1.58) ; p=0.375\end{array}$ \\
\hline Pascuet $\mathrm{E}$ et al. ${ }^{13}$ & $\begin{array}{l}\text { No difference/ } \\
\text { controversial }\end{array}$ & $\begin{array}{l}\text { Median no. of emergency department visits per month after intervention: }-0.03 \\
(95 \% \mathrm{Cl}-0.09 \text { to } 0.02) ; p=0.20 \\
\text { Median no. of outpatient visits per month after intervention }-0.5(95 \% \mathrm{Cl}-1.0 \text { to }-0.05) \text { : } \\
p=0.029\end{array}$ \\
\hline
\end{tabular}


ular device (RR 2.8, 95\% CI1.6-5.0). The second study ${ }^{14}$ reported a lower proportion of intubations in the final 24 hours of life $(21 \% \mathrm{v} .48 \%, p=0.029)$, with no difference in the proportion of withdrawal of other support measures $(36 \%$ v. $19 \%, p=0.123)$, among cancer patients who had a planned location of death versus those who did not.

Two cohort studies examined resuscitation interventions. One study ${ }^{12}$ showed that, among children who died from any cause, those with a palliative care consultation had a significantly lower relative risk of cardioversion (RR 0.49, 95\% CI 0.38-0.62) than those without a consultation. The second study ${ }^{14}$ reported a lower proportion of cardiopulmonary resuscitation attempts among cancer patients who had a planned location of death ( $4 \%$ v. $19 \%, p=0.142)$ versus those who did not.

\section{Interpretation}

The primary articles investigating the influence of PPCP on health care utilization showed fewer hospital admissions among children enrolled in PPCPs ${ }^{10,14}$ and fewer planned hospital admissions among cancer patients in such programs. ${ }^{11}$ The overall number of hospital, emergency and outpatient admissions was not affected. ${ }^{11,13,14,18}$ Conflicting results were observed with regard to the proportion of patients undergoing critical care. ${ }^{12,19}$ Most of the studies showed shorter hospital stays among PPCP users. ${ }^{5,10,13,14,18}$ When inpatient time in hospice facilities was considered, ${ }^{13}$ length of stay became longer for PPCP patients. Regarding costs of health care, no conclusive impact of PPCPs could be drawn from the primary studies ${ }^{5,12,13,15-18}$ owing to conflicting results and heterogeneity in comprehensiveness of outcome measures. From the more comprehensive studies that included hospice and hospital costs, we observed an overall decrease in costs in the Canadian health care setting ${ }^{13}$ and an increase in the American setting. ${ }^{15}$ For end-of-life admissions, PPCP users had a shorter stay ${ }^{12}$ and less aggressive care to prolong life. ${ }^{12,14}$ However, focusing solely on hospital utilization has limitations, because it does not consider impacts on the health care system in totality, nor the financial burden borne by families. More rigorous study designs with broader perspectives that include expected costs incurred in other settings should be undertaken.

Interpreting the reviewed studies was challenging because of numerous limitations of the primary articles, and study contexts. Questions remain regarding risk of bias, selection and identification of participants, and intervention classification. Most of the studies focused on hospital admissions and did not account for other types of resource utilization (hospice, home care, other facilities). Studies that showed a decrease in length of stay among PPCP users ${ }^{5,10,17,18}$ did not investigate the number of days spent in hospice or other facilities, which again leaves uncertainty as to whether a decrease in resource utilization or a shift in health care setting occurred.

The only study that measured both hospital and hospice admissions found an increase in the total combined length of stay, which showed a shift in the setting of health care utilization from hospital to hospice. ${ }^{13}$ Despite this shift, a significant decrease in monthly costs was observed, owing to the difference in average daily costs between settings in the Canadian health care system. A similar trend was shown in the US by Gans and colleagues, ${ }^{5}$ who found a shift in resource utilization, from a decline in inpatient care costs to a surge in outpatient care and pharmaceutical costs. Nonetheless, an overall $11 \%$ decrease in health care costs after the implementation of the community-based PPCP occurred. However, this study neither tested for statistical significance nor adjusted for survival time after program enrolment. Conversely, another American study ${ }^{15}$ found hospice users to have higher expendi-

Table 4: Effect of pediatric palliative care programs versus usual care on length of stay

\begin{tabular}{|c|c|c|}
\hline Study* & Summary & Outcome \\
\hline Postier et al. ${ }^{18}$ & Decrease & $\begin{array}{l}\text { Mean total LOS } \pm \text { SD: } 34.09 \pm 59.7 \mathrm{~d} \text { before } v .19 .37 \pm 34.0 \mathrm{~d} \text { after intervention; } p<0.001 \\
\text { Interaction: level of exposure to program, noncancer and study period }(p<0.001)\end{array}$ \\
\hline Arland et al. ${ }^{10}$ & Decrease & $\begin{array}{l}\text { Mean LOS per hospital admission: } 3.03 \text { after v. } 4.05 \text { d before intervention; } 25 \% \text { decrease } \\
\text { (no test applied) } \\
\text { Mean LOS per patient overall (not only among those admitted to hospital): } 1.25 \text { d after v. } \\
3.68 \text { d before intervention; } 66 \% \text { decrease (no test applied) }\end{array}$ \\
\hline Dussel et al. ${ }^{14}$ & $\begin{array}{l}\text { No difference/ } \\
\text { controversial }\end{array}$ & $\begin{array}{l}\text { Median (IQR) LOS in last mo of life: } 17 \text { (4-27) d in intervention group v. } 21 \text { (6-28) d in } \\
\text { control group; } p=0.494\end{array}$ \\
\hline Ward-Smith et al. ${ }^{17}$ & $\begin{array}{l}\text { No difference/ } \\
\text { Controversial }\end{array}$ & Mean LOS (range): 4 (5 to 17) d in intervention group v. 4 (5 to 18$) \mathrm{d}$ in control group \\
\hline Gans et al. ${ }^{5}$ & Decrease & $\begin{array}{l}\text { Mean LOS per patient per mo: } 4.0 \text { before v. } 2.8 \text { after intervention; } 32 \% \text { decrease (no test } \\
\text { applied) }\end{array}$ \\
\hline Pascuet et al. ${ }^{13}$ & Increase & $\begin{array}{l}\text { Median no. of days in hospital per mo (range) after intervention: }-2.9(95 \% \mathrm{Cl}-4.5 \text { to }-1.3) \text {; } \\
p=0.001 \\
\text { Median no. of days in hospice per mo (range) after intervention: } 2.4(0.08-26.5) \\
\text { Variation in median no. of total inpatient days per mo after intervention: } 0.9(p=0.013)\end{array}$ \\
\hline
\end{tabular}




\section{OPEN}

tures in all types of admissions (hospice, inpatient, outpatient, emergency department) and pharmacy expenses. This study allocated patients to the PPCP group based on billing codes for hospice services. However, some patients in the non-hospice user group died at the hospice, which showed the limitation of using billings to identify patients. It is unclear whether costs of health care differ when studies refer to them as charges, expenditures or costs. Another important limitation was observed by Belasco and colleagues ${ }^{16}$ who listed the procedures/services received at home and estimated the equivalent cost at the tertiary care centre. Costs were discrepant, however, because the authors did not account for uninsured home care procedures. It is unclear whether these were outof-pocket costs for the families or waived by health care providers. Therefore, charges did not appropriately reflect costs, which introduced important measurement bias.

\section{Limitations}

Despite a thorough search of the literature with no language restrictions, we were unable to identify relevant randomized controlled trials or prospective studies. We included only studies that compared palliative care and usual care. No indi- rect comparison was contemplated with single-arm observational studies. According to the Newcastle-Ottawa Scale quality assessment, the overall quality of evidence was moderate to low. In particular, the risk of selection bias to PPCP (given the nature of the referral process) is of major concern. Furthermore, information bias and misclassification is a threat to internal validity in observational studies based on secondary databases. The considerable heterogeneity in outcome measures, observation period, scope of PPCP elements provided by the programs, characteristics, reporting of program components, and whether reported interventions accurately represented the enrolment of children and families in a PPCP are worth noting. Information bias may have affected the allocation of patients to groups. Because PPCP is a relatively new and evolving specialty, the mode of recording services (claims, bills and codes) may have changed over time. Consequently, the use of palliative care services could have been underreported or reported differently from usual care. Furthermore, practitioners in both PPCP and usual care may provide either type of care to children in both groups (e.g., increasing curative efforts for children in a PPCP or focusing on palliative care for those in usual care), which would affect coding and

Table 5: Effect of pediatric palliative care programs versus usual care on costs

\begin{tabular}{|c|c|c|}
\hline Study* & Summary & Outcome \\
\hline Postier et al. ${ }^{18}$ & Decrease & $\begin{array}{l}\text { Mean charges } \pm \text { SD (factor of } \$ 10000): 20.97 \pm 43.3 \text { before v. } 10.91 \pm 21 \text { after } \\
\text { intervention; } p<0.001 \\
\text { Interaction: level of exposure to program, cancer/noncancer, study period }(p<0.001)\end{array}$ \\
\hline Knapp et al. ${ }^{15}$ & Increase & $\begin{array}{l}\text { Total mean expenditures (hospice v. nonhospice users): } \\
\text { All causes of death: } \$ 83719 \text { v. } \$ 36597 \\
\text { Perinatal: } \$ 112723 \text { v. } \$ 78218 \\
\text { Chronic: } \$ 84047 \text { v. } \$ 66584 \\
\text { [Note: The total cost is the sum of the mean expenditures per type (inpatient, outpatient, } \\
\text { hospice and pharmacy). For more details visit the primary article.] }\end{array}$ \\
\hline Keele et al. ${ }^{12}$ & Decrease & $\begin{array}{l}\text { Median (IQR) daily charges, adjusted for geography: } \$ 9348(\$ 6070-\$ 15318) \text { in } \\
\text { intervention group v. } \$ 11806 \text { ( } \$ 8017 \text { to } \$ 18352 \text { ) in control group; } p<0.001\end{array}$ \\
\hline Smith et al. ${ }^{19}$ & Increase & $\begin{array}{l}\text { Change in median daily cost (IQR) within intervention group: } \$ 3827 \text { ( } \$ 2.9 \mathrm{~K}-3.9 \mathrm{~K}) \text { before v. } \\
\$ 4013(\$ 3.1 \mathrm{~K}-5.1 \mathrm{~K}) \text { after intervention; } p=0.06 \\
\text { Median daily cost (IQR) in } 2010 / 11: \$ 3.8 \mathrm{~K}(\$ 3.1 \mathrm{~K}-\$ 4.7 \mathrm{~K}) \text { in intervention group v. } \$ 3.4 \mathrm{~K} \\
(\$ 2.7 \mathrm{~K}-\$ 4.5 \mathrm{~K}) \text { in control group; } p=0.001\end{array}$ \\
\hline Ward-Smith et al. ${ }^{17}$ & $\begin{array}{l}\text { No difference/ } \\
\text { controversial }\end{array}$ & $\begin{array}{l}\text { Mean hospital costs (range), excluding surgical charges: } \$ 78780 \text { ( } \$ 33283 \text { to } \$ 130970 \text { ) in } \\
\text { intervention group v. } \$ 81780 \text { ( } \$ 28970 \text { to } \$ 135432 \text { ) in control group }\end{array}$ \\
\hline Gans et al. ${ }^{5}$ & Decrease & $\begin{array}{l}\text { Mean total medical expenditures per patient per mo: } \$ 15653 \text { before v. } \$ 13976 \text { after } \\
\text { intervention } \\
11 \% \text { decrease overall: nearly } \$ 1 \text { million in } 18 \text { mo }(35 \% \text { decrease inpatient care costs } \\
\text { [\$3571]; } 34 \% \text { increase in outpatient care costs }[\$ 1398] ; 35 \% \text { increase in pharmaceutical } \\
\text { costs [ } \$ 495])\end{array}$ \\
\hline Pascuet et al. ${ }^{13}$ & Decrease & $\begin{array}{l}\text { Change in total inpatient costs per mo (hospital + hospice): }-\$ 4252(95 \% \mathrm{Cl}-\$ 953 \text { to } \\
-\$ 7551) \text { after intervention; } p=0.012 \\
\text { Unit costs per d: } \$ 2007 \text { hospital inpatient v. } \$ 500 \text { hospice }\end{array}$ \\
\hline Belasco et al. ${ }^{16}$ & Decrease & $\begin{array}{l}\text { Mean charges per d (hospital v. home): } \\
\text { Acute myeloid leukemia (toddler): } \$ 4283 \text { v. } \$ 17 \\
\text { Neuroblastoma (preschool child): } \$ 2300 \text { v. } \$ 325 \\
\text { Multiple chronic diseases (teenager): } \$ 8258 \text { v. } \$ 1308\end{array}$ \\
\hline
\end{tabular}


classification. Moreover, the specific context and funding models for the different health care systems may have affected the results. Therefore, both the evidence and its applicability should be interpreted with caution.

\section{Conclusion}

The published evidence to support the planning and reallocation of resources for PPCPs by estimating their impact on health care resource utilization and costs was of moderate to low methodologic quality. Depending on the health care system, PPCP may increase costs, but in the Canadian context, they may be cost saving. The paucity of evidence with broad approaches to measurement is not only in conflict, but very context dependent. Prospective studies are needed to evaluate the overall impact of PPCPs on the health care system from perspectives beyond that of the tertiary care provider, while measuring shifts in health care settings and family burden. Improved study designs can address the various aforementioned biases and classification issues. Standardization of outcome measures can enhance comparability and pooling of findings from future studies. Noting these limitations, this review provides an important first step toward a more comprehensive understanding of the impact of PPCPs on resource utilization across various health care settings.

\section{References}

1. A guide to the development of children's palliative care services. Association for Children's Palliative Care; 2009:34. Available: www.togetherforshortlives.org.uk /professionals/resources/2430_a_guide_to_the_development_of_childrens palliative care services (accessed 28 Jan. 2015).

2. Harrop E, Edwards C. How and when to refer a child for specialist paediatric palliative care. Arch Dis Child Educ Pract Ed 2013;98:202-8.

3. Groh G, Feddersen B, Führer M, et al., Specialized home palliative care for adults and children: differences and similarities. 7 Palliat Med 2014;17:803-10.

4. Liberati A, Altman DG, Tetzlaff J, et al. The PRISMA statement for reporting systematic reviews and meta-analyses of studies that evaluate health care interventions: explanation and elaboration. BM7 2009;339:b2700.

5. Gans D, Kominski GF, Roby DH, et al. Better outcomes, lower costs: palliative care program reduces stress, costs of care for children with life-threatening conditions. Los Angeles: UCLA Center for Health Policy Research; 2012.

6. Hays RM, Valentine J, Haynes G, et al.The Seattle Pediatric Palliative Care Project: effects on family satisfaction and health-related quality of life. 7 Palliat Med 2006;9:716-28.

7. Earle CC. Identifying potential indicators of the quality of end-of-life cancer care from administrative data. 7 Clin Oncol 2003;21:1133-8.

8. Wells G, Shea B, O'Connell D, et al. The Newcastle-Ottawa Scale (NOS) for assessing the quality of nonrandomised studies in meta-analyses. Ottawa: Ottawa Hospital Research Institute; 2009. Available: www.ohri.ca/programs /clinical epidemiology/oxford.asp (accessed 2015 Jan. 8).

9. Fleiss J, Levin B, Paik M. Statistical methods for rates and proportions. 3rd ed. London (UK): John Wiley \& Sons; 2003:598-626.

10. Arland LC, Hendricks-Ferguson VL, Pearson J, et al. Development of an inhome standardized end-of-life treatment program for pediatric patients dying of brain tumors. 7 Spec Pediatr Nurs 2013;18:144-57.
11. Fraser LK, van Laar M, Miller M, et al. Does referral to specialist paediatric palliative care services reduce hospital admissions in oncology patients at the end of life? Br 7 Cancer 2013;108:1273-9.

12. Keele L, Keenan HT, Sheetz J, et al. Differences in characteristics of dying children who receive and do not receive palliative care. Pediatrics 2013; 132:72-8.

13. Pascuet E, Cowin L, Vaillancourt R, et al. A comparative cost-minimization analysis of providing paediatric palliative respite care before and after the opening of services at a paediatric hospice. Healthc Manage Forum 2010;23: 63-6.

14. Dussel V, Kreicbergs U, Hilden JM, et al. Looking beyond where children die: determinants and effects of planning a child's location of death. 7 Pain Symptom Manage 2009;37:33-43.

15. Knapp CA, Shenkman E, Marcu M, et al. Pediatric palliative care: describing hospice users and identifying factors that affect hospice expenditures. 7 Palliat Med 2009; 12:223-9.

16. Belasco JB, Danz P, Drill A, et al. Supportive care: palliative care in children, adolescents, and young adults-model of care, interventions, and cost of care: a retrospective review. 7 Palliat Care 2000;16:39-46.

17. Ward-Smith P, Korphage RM, Hutto C. Where health care dollars are spent when pediatric palliative care is provided. Nurs Econ 2008;26:175-8.

18. Postier A, Chrastek J, Nugent S, et al. Exposure to home-based pediatric palliative and hospice care and its impact on hospital and emergency care charges at a single institution. 7 Palliat Med 2014;17:183-8.

19. Smith A, Andrews S, Maloney C, et al. Pediatric palliative care in high cost patients. In: Poss WB, editor. Pediatric critical care medicine. Conference: American Academy of Pediatrics, Section on Critical Care National Conference and Exbibition.Vol 26. Orlando (FL): Lippincott Williams and Wilkins; 2013. Available: https://aap.confex.com/aap/2013/webprogram/Paper21649.html (accessed 2015 Jan. 8).

20. Phillimore P, Beattie A, Townsend P. Widening inequality of health in northern England, 1981-91. BMF 1994;308:1125-8.

Affiliations: School of Population and Public Health (Conte, Mitton, Trenaman, Chavoshi), University of British Columbia; Centre for Clinical Epidemiology and Evaluation (Conte, Mitton, Trenaman); Canuck Place Children's Hospice (Chavoshi, Siden); Child and Family Research Institute (Siden); Division of General Pediatrics (Siden), Department of Pediatrics, University of British Columbia, Vancouver, BC

Contributors: Tania Conte, Craig Mitton, Negar Chavoshi and Harold Siden contributed to the study concept, and Tania Conte and Craig Mitton to the study design. Tania Conte and Logan Trenaman contributed to the acquisition of data. Tania Conte, Logan Trenaman, Craig Mitton, Negar Chavoshi and Harold Siden contributed to the analysis and interpretation of data. Tania Conte drafted the article; all of the authors revised it critically for important intellectual content, approved the final version submitted for publication and agreed to act as guarantors of the work.

Funding: This review did not receive funding and is part of a masters thesis project for the School of Population and Public Health at the University of British Columbia. Tania Conte and Logan Trenaman were funded by External Graduate Awards (Pfizer HTAcademy Scholarships) for students in the Health Economics Concentration.

Acknowledgement: The authors acknowledge the contribution of Madeleine Doyle-Waters, librarian at the Centre for Clinical Epidemiology and Evaluation, who supported the construction and optimization of the search strategies.

Supplemental information: For reviewer comments and the original submission of this manuscript, please see www.cmajopen.ca/content/3/1 /E68/suppl/DC. 